\title{
PASSIVE HOUSE
}

\section{George-Lucian IONESCU}

\author{
${ }^{\text {a }}$ Lecturer eng. PhD, University of Oradea, Faculty of Civil Engineering, Cadastre and Architecture, \\ Department of Constructions, no. 4, Barbu Stefanescu Delavrancea Street, code 410058, Oradea, Romania, \\ e-mail: lucian.ionescu1985@yahoo.com
}

Received: 16.01.2017 / Accepted: 20.01.2017 / Revised: 25.04.2017 / Available online: 31.05.2017

\section{DOI: 10.1515/jaes-2017-0003}

Keywords: Passive House, sustainable development, sustainability, recovery, reuse

\begin{abstract}
:
This paper outlines for construction specialists the concept of "passive house", presenting the actual status of research and breakthroughs within this field within the country and abroad but also the directives of the European Council and European Parliament regarding this concept. Last, but certainly not least, it showcases some of the flaws of the European Directive regarding passive houses, because it fails to bring forth viable solutions for a number of dire issues.
\end{abstract}

\section{PRELIMINARIES}

Since the year 2009, the European Parliament and the European Council have decreed a directive through which the European Union's member states need to develop a special legislative framework by the year 2020, which is meant to ensure the application of the new Passive House standards for every home or new residential building. But even so, there are already voices that affirm that the new passive houses need to be even more eco-friendly.

In the year 2011, the European Parliament politicians (source: $\quad$ http://europa.eu/rapid/press-release IP-091733 en.htm?locale=en) have been finally convinced to speed up the application of certain measures through which to ensure the stopping of environmental pollution brought forth by residential buildings or at the very least to diminish it sufficiently so as to significantly reduce the effects of global warming. The specialists' estimations are that, in Europe, $40 \%$ of all energy produced is used in housing and $36 \%$ of the $\mathrm{CO}_{2}$ emissions are caused by the residential housing sector.

Thus, if the way in which residential housing is realized is radically changed, as well as the means through which energy is consumed, we can properly assist in the drastic reduction of residential housing pollution. The EU specialists also hope to reduce this level below the target that has been proposed by the Kyoto Treaty. Furthermore, any new constructions of the "passive house" type could represent a significant economy of approx. 300 euros per year for each household within the European Union, as well as also positively impulsing the constructions sector, with direct benefits for each country's economy.

A passive house is thus a type of house that manages to keep a comfortable temperature, even during the cold season, without the use of a specific heating system. The "passive" term is used because the main heating source is the sun and the heat that is emitted by the residents themselves, by the household appliances, by the heat that is passively consumed by the house without the need for special and/or dedicated heating systems (Schnieders 2003).

A passive house is defined as being a house with a yearly maximum requirement of $15 \mathrm{kWh} / \mathrm{m}^{2}$ used for heating (Husbanken 2004). The standard was first developed by Wolfgang Feist, and is now regulated by the "Passive Hause" German Institute for passive houses (Gligor et.al., 2013).

Even if the standard is defined by the consumption of energy that is necessary for heating, the concept of a passive house also presumes the drastic reduction (towards minimum) of energy consumption, that is found in other potential energy consuming sources within the building.

The main objective is to maintain a total energy consumption of $120 \mathrm{kWh} / \mathrm{m}^{2} \cdot \mathrm{a}$. 


\section{THE ACTUAL STATUS OF RESEARCH AND DEVELOPMENT OF PASSIVE HOUSES WITHIN THE COUNTRY AND ABROAD}

The Passive House concept has been conceived in Germany in the year 1983, when the Institute of Passive Houses was established in the city of Darmstad.

In the year 1991 the first passive house was developed in the Darmstad. Ever since then, thousands of passive buildings have been developed, from individual housing to residential blocks, schools, city halls etc.

If at the beginning of 2007 , there were 8000 passive units constructed in Germany, today their number has reached 12500 units. In the Baden-Wuerttemberg region in Germany the ratio presents that there are 2,4 passive houses for 100,000 residents.

In Romania there are certain buildings of passive type that are developed by the AMVIC company These houses are developed by means of neophor thermo-insulant sheets, having $U=0,11$ $\mathrm{W} / \mathrm{m}^{2} \cdot{ }^{0} \mathrm{~K}$, where the thickness of the thermoinsulating layer is $24,3 \mathrm{~cm}(6,35+18 \mathrm{~cm})$ and the thickness of the concrete layer is $20,3 \mathrm{~cm}$. The AMVIC company also has its headquarters from Bragadiru, Romania built as a passive building.

The SC FOLEX SRL company from Aiud, builds passive type houses, based on the FOLEX BSF bricks, a rapid solution that is prefinished and competitive and alternative to conventional construction materials. The bricks are the result of the company's specialists' research activities and consist of prefab materials from polyurethane foam with holes.

An approach of the passive house concept can be generally perceived as being composed out of five base elements. Three of them (thermal insulation, heat retrieval and solar contribution) refer to the heating properties of the building, while the remaining two (electrical potential and ensuring the energetic requirements of all other necessities by means of renewable sources) are necessary for fully minimizing the impact the building has over the environment (Ionescu, G.L., 2017).

\section{Optimised heat insulation means:}

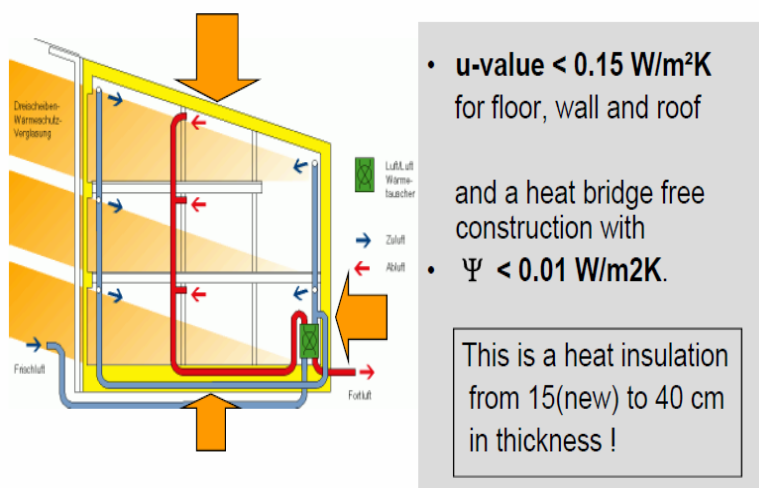

That means for the windows:

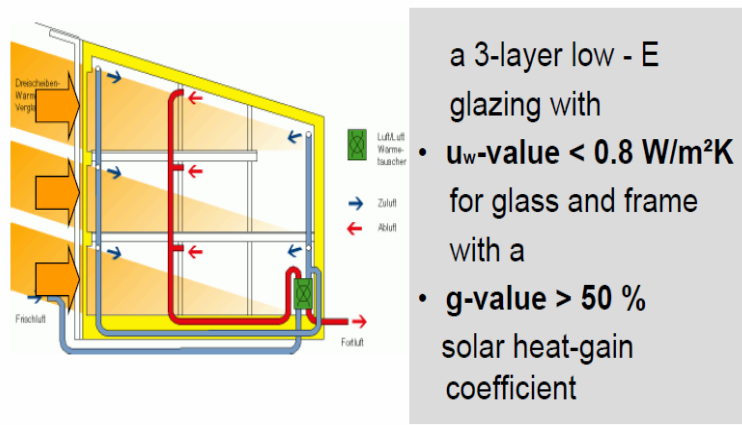

Solar energy contribution is approx. one third of the thermal energy requirements of a passive house. In order to realize this, there needs to be a direct net contribution from the windows. This is realized by means of extremely lowered heat loss through windows, high efficiency frames and the general orientation of the building facing south. The windows need to have a $U$ value less than $0,8 \mathrm{~W} /$ $\mathrm{m}^{2} \cdot{ }^{0} \mathrm{~K}$.

\section{That means for the air-tightness:}

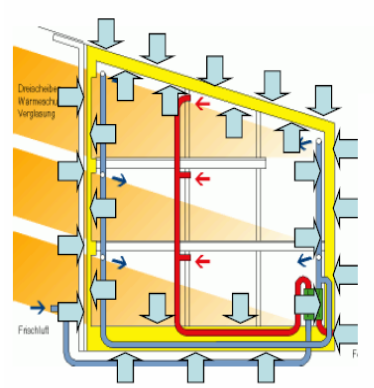

Air leakage through unsealed joints must be less than

- $\mathrm{n}_{50}<0.6$ house volume/h

Blower door test with a $+/$ - pressure of 50 Pascal. 
A sufficiently efficient system of heat retrieval is a primary element in meeting the standards of a passive house. The retrieval rate for hear must exceed $75 \%$, which can be realized by means of heat exchangers. The ventilation system needs the be extremely energy efficient.

\section{The comfort ventilation system effects:}

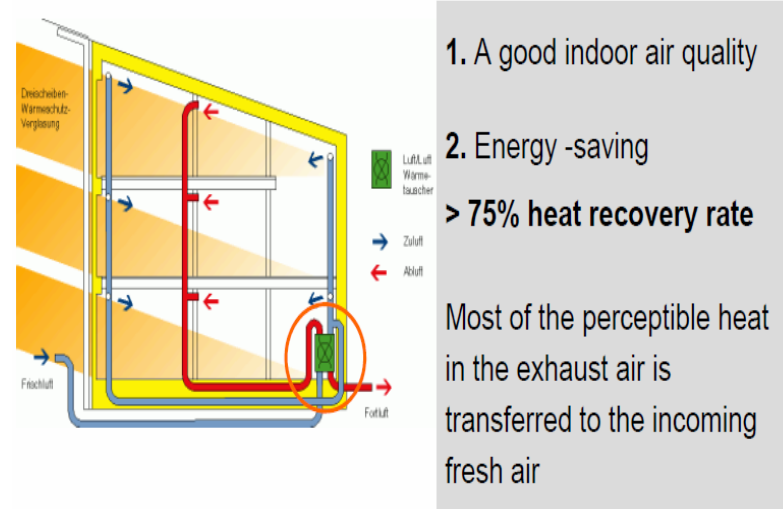

A passive warming of fresh air makes sense:

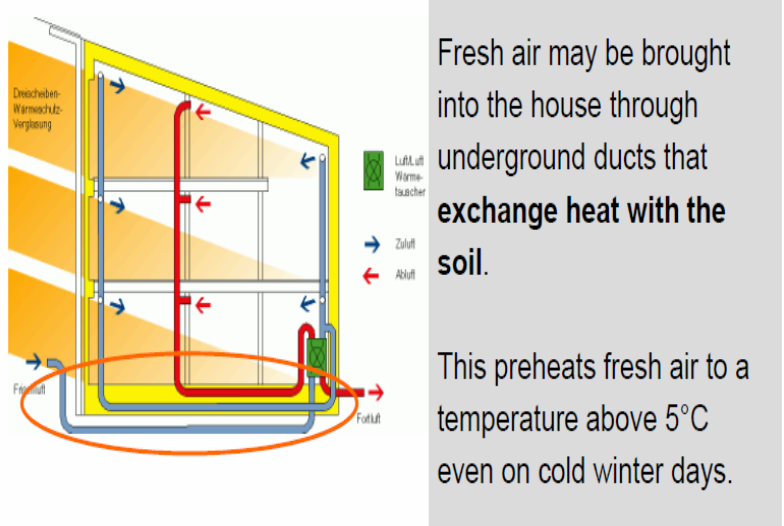

\section{A passive warming of fresh air makes sense:}

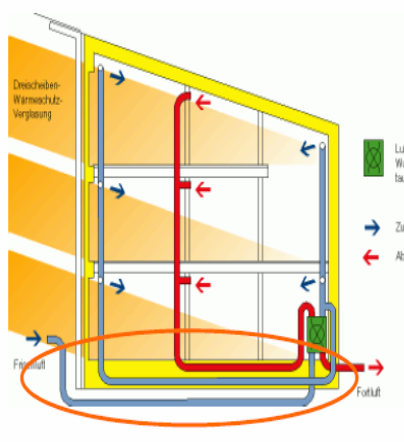

\section{Fresh air may be brought} into the house through

ume underground ducts that

exchange heat with the $\rightarrow \rightarrow$ soil.

This preheats fresh air to a temperature above $5^{\circ} \mathrm{C}$ even on cold winter days.

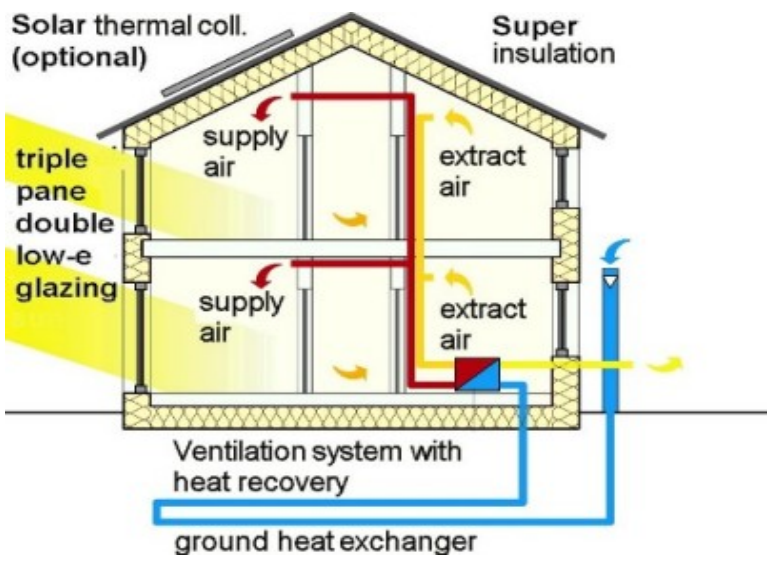

Figure 1. Functional scheme of a ventilation system with heat recirculation

In theory, a passive house is a construction which presumes an energy consumption that is reduced as much as possible with the condition that, at the same time, it presents a reasonably high comfort level. This has lead to that the term "Passive House" represents not only a constructive concept but for it to be developed into a unitary standard in conceiving and construction of buildings, in other words, a standard that offers a high energetic efficiency throughout its entire lifespan, the main objective being "near zero emissions". Due to the fact that it entwines a slow technological transition on a global scale, as in, until the complete transition from non-renewable energy sources (such as coal and petroleum) to completely renewable sources, the EU officials have stated that half a century must first pass for this to be fully feasible, emission wise on the global scale.

The first Passive House type building in France was built in 2009 boasting bio-friendly materials, heating and electrical energy ensured by the sun and ventilation by means of heat recovery. Source: (www.homedsgn.com)

"The construction that offers the best economic performance in regards to investment cost, energy consumption and operational costs, in regards to local climatic conditions can be considered as having an almost zero energy consumption. The renewable energies that are produced locally are those that ensure, in this case, the total energy required for heating, household hot water needs and electrical current needs."

The above mentioned definition was brought forward by PHI ((Passive House Institute), an independent research institute in the field of passive houses from Germany. This institute brings forward the fact that the EU should adapt the required criteria for conceiving a standardized "Passive House" future, in regards to the development of ecofriendly technologies. In other words, we should abandon our current methods of efficiency calculations that are based on petroleum consumption for ensuring the energy requirements (Iancau et.al., 2012). 


\section{Heating energy $\mathrm{kWh} /\left(\mathrm{m}^{2} \mathrm{yr}\right)$}

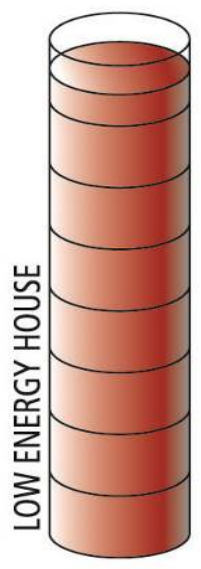

80

70

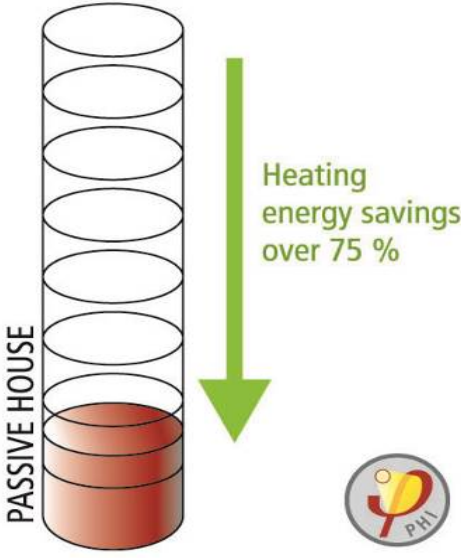

Figure 2. Energy efficiency of a passive house

According to actual conception, a passive house requires $75 \%$ less burnt fuel, which is considered as being still not enough to sufficiently reduce environmental pollution. The EU specialists consider that for a passive house it is needed to annually burn approx. 1,5 liters of fossil fuel for each square meter, which does indeed represent a $75 \%$ reduction in energy consumption when compared to a new house and over $90 \%$ reduction when compared with the conventionally built houses that were erected during the last half century. Even so, taking into account the fact that usually a household exceeds 100 square meters as usable surface, it would require 1.500 liters of fuel, which brings the average level of $\mathrm{CO}_{2}$ emissions to at least one ton for each household that was built as a passive house within the EU. One thing that can be avoided (or further diminished) if taken into consideration, even imposed upon, is the development and optimization of technologies regarding obtaining energy from renewable sources.

Furthermore, the people over at PHI shed light on the deficiencies of the European Union's Directive over passive houses because it fails to bring solutions over issues that are considered gravely important:

- the use of fossil fuels is no longer predictable (the diminishing quantities of available resources leads to an increase in their price) which directly affects the estimates regarding costs and dampening of a passive house investment - it is possible that the 300 euro's economy stipulated by the EU to not occur at all, more likely to even lead to an unjustified increase of the factors

- the connecting influences of pollution are not taken fully into consideration in the case of using non-renewable energy sources (such as nuclear waste) and the reduction in $\mathrm{CO}_{2}$ emissions is considered insufficient for stopping global warming and the drastic climate changes

- $\quad$ in the case of renewable sources such as biomass, the estimates are not realistic, because, unlike the sun, wind or heat of the earth, biomass is limited, thus an

inefficient use of biomass can lead to grave negative effects upon the environment (taking into account the massive exploitation of forested areas but also the intensive agriculture)

- the evolutions in the field of energy storage are not taken into account - EU officials still rely on the large scale energy source delivery which proposes a lot of energy loss by comparison to solutions which take full use of energy capacitors, which is predicted to be used on an ever larger scale with the dawn of the second half of this decade.

$\bullet$

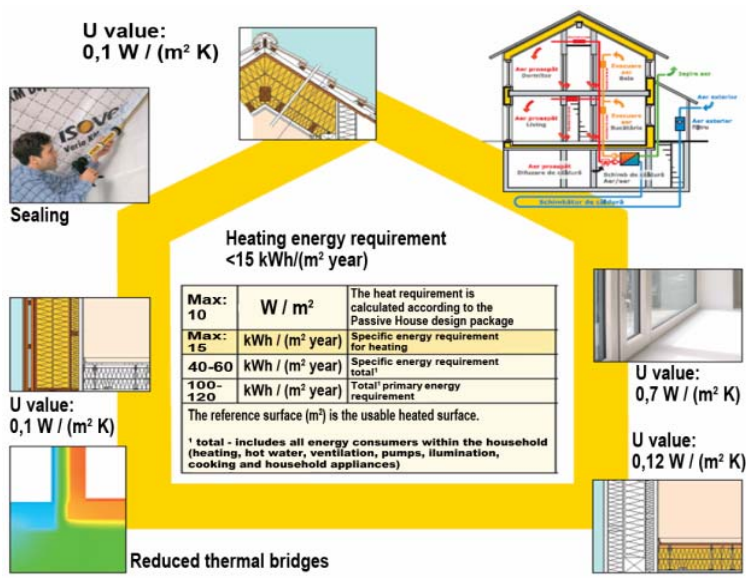

Figure 3. Principle scheme, by which an energy requirement can be obtained for heating purposes, under $15 \mathrm{kWh} / \mathrm{m}^{2} \cdot$ year

Thus, the European Parliament needs to realize that good intentions are not sufficient when the issue is the reduction of pollution, but coherent measures and rapid adaptation in regards to the evolution of technology are needed in parallel with pragmatic estimations - let's not forget that the objectives for 2020 have been brought forth and discussed upon a decade earlier, in the conditions in which both the economic-political medium but also the climate and the environment have shown dramatic changes in the span of just a few years.

Lastly, however drastic it would seem from a social point of view, the objective of the authorities should be "zero emissions" not just "almost zero emissions" - thus, major modifications of the standardized Passive House future are in store.

Based on the thermos bottle principle, the passive house keeps a constant pressure - the interior being well protected by the energy losses towards the exterior.

Unlike conventional buildings which boast large heat losses towards the exterior, within a passive house, the heat that is emitted by people, animals and household appliances is very important in ensuring the building's heating potential. 


\section{PASSIVE HOUSE MODEL. HOUSE BUILT FROM HEMP}

Source: http://casepractice.ro/case-din-cânepă-absorb-co2/

In a lot of European countries, in Asia, Australia as well as in the USA, in the last few years there have been houses built using hemp as a primary building material. These are built from "bricks" made out of a mixture of industrial hemp stem, water and lime, a mixture that becomes ever more resistant as time passes on (Ionescu, G.L., 2017).

The insulation of these buildings is very good, while at the same time allowing the walls to "breathe".

Hemp has proven to be a natural material, biodegradable and resistant against pests that are able to absorb the carbon bioxide, which makes it so that such a house is extremely healthy as a living medium.

In the United States of America, the first hemp house is found in Ashville, North Carolina, and was built by a team of 40 volunteers and employees of the construction company and was designed by the ecological design firm "Push Design".

"We have always sought the ideal non-toxic material which would also be durable and efficient in regards to the energetic factor, an effort we have endeavored in daily. We have found that the hemp plant is ideal in this task in all aspects, save its cost, the most efficient and durable material currently available at a global scale" was stated by David Mosrie, from Push Design.

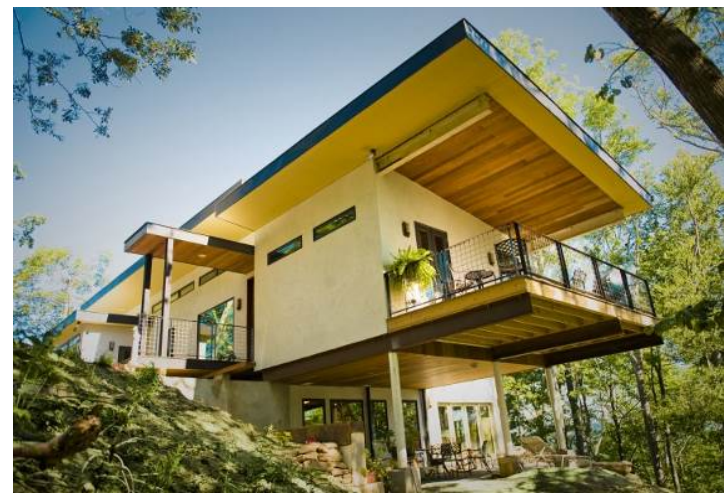

Figure 4. Hemp House model; Ashville, North Carolina

Hemp stem is a wooden like material, with a high level of porosity and rich in silica bioxide. It is used by being mashed and mixed with lime. When these two components enter in the mixture and react with one another, a long mineralization process takes place, resulting in a more solid wall, boasting sturdiness close to that of limestone.

The lifespan of hemp based houses is, according to certain studies, approximately 600-800 years.

Both the thermal and phonic insulation of hemp based walls is extremely good. Mold occurrence is completely negated, a good circulation of air is ensured between the interior and exterior and they are very resistant against pests and are capable of a great $\mathrm{CO}_{2}$ absorption, a lot more than was emitted by means of their construction.

The house built in Ashville has its interior padded with panels made out of recycled paper. The doors with frames made out of massive wood are made out of the same material and are very light. The window frames have been recycled from demolished buildings, the old window glass being replaced by more heavy glass which boast better insulation. The construction of the first house took nine months, Mosrie estimating that future such endeavors would have the construction time halved.

The British company "Modece Architects" has developed a model for such a house, specializing itself in construction of hemp based passive housing.

Utilizing the modern technologies in passive house construction, the company utilizes hemp bricks and limeplaster instead of cement and expanded polystyrene for thermal insulation of the buildings.

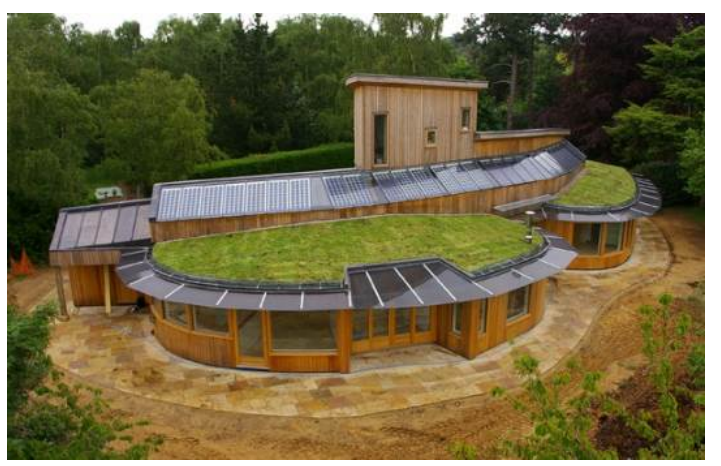

Figure 5. Model of a hemp based passive house, developed by British company „Modece Architects”

\section{REFERENCES}

Ionescu, GH. C. (Coordonator lucrare), Autori: Gligor Emil, G.L. Ionescu, Daniela Gavriş (2013), Instalații pentru construcții - Suport laborator, Editura Aureo, Oradea.

George - Lucian Ionescu (2017), Instalații pentru construcții, Editura MatrixRom Bucureşti.

Marcel Mugurel Iancău, Gheorghe -Constantin Ionescu, Raul Stelian Balota (2012), Passive house design in Romania as an influence of weather data analyses - The 9th edition of World Energy System Conference, WESC 2012, June 28-30 2012 Suceava, Romania - Towards a sustainable and integrated energy system ISSN-L 12247928. 